\title{
Joint effects of storm surge and sea-level rise on US Coasts: new economic estimates of impacts, adaptation, and benefits of mitigation policy
}

\author{
James E. Neumann • Kerry Emanuel • Sai Ravela • \\ Lindsay Ludwig • Paul Kirshen • Kirk Bosma • \\ Jeremy Martinich
}

Received: 7 March 2014 / Accepted: 2 December 2014 / Published online: 14 December 2014

(C) The Author(s) 2014. This article is published with open access at Springerlink.com

\begin{abstract}
Recent literature, the US Global Change Research Program's National Climate Assessment, and recent events, such as Hurricane Sandy, highlight the need to take better account of both storm surge and sea-level rise (SLR) in assessing coastal risks of climate change. This study combines three models - a tropical cyclone simulation model; a storm surge model; and a model for economic impact and adaptation - to estimate the joint effects of storm surge and SLR for the US coast through 2100. The model is tested using multiple SLR scenarios, including those incorporating estimates of dynamic ice-sheet melting, two global greenhouse gas (GHG) mitigation policy scenarios, and multiple general circulation model climate sensitivities. The results illustrate that a large area of coastal land and property is at risk of damage from storm surge today; that land area and economic value at risk expands over time as seas rise and as storms become more intense; that adaptation is a cost-effective response to this risk, but residual impacts remain after adaptation measures are in place; that incorporating site-specific episodic storm surge increases national damage estimates by a factor of two relative to SLR-only estimates, with greater impact on the East and Gulf coasts; and that mitigation of GHGs contributes to significant lessening of damages. For a mid-range
\end{abstract}

Electronic supplementary material The online version of this article (doi:10.1007/s10584-014-1304-z) contains supplementary material, which is available to authorized users.

J. E. Neumann $(\triangle) \cdot$ L. Ludwig

Industrial Economics, 2067 Massachusetts Avenue, Cambridge, MA 02140, USA

e-mail: jneumann@indecon.com

K. Emanuel $\cdot$ S. Ravela

WindRiskTech, L.L.C., and Massachusetts Institute of Technology, Cambridge, MA, USA

P. Kirshen

University of New Hampshire, Durham, NH, USA

K. Bosma

Woods Hole Group, Falmouth, MA, USA

J. Martinich

Climate Change Division, USEPA, Washington, DC, USA 
climate-sensitivity scenario that incorporates dynamic ice sheet melting, the approach yields national estimates of the impacts of storm surge and SLR of $\$ 990$ billion through 2100 (net of adaptation, cumulative undiscounted 2005\$); GHG mitigation policy reduces the impacts of the mid-range climate-sensitivity estimates by $\$ 84$ to $\$ 100$ billion.

\section{Introduction}

Recent events have heightened the concern of coastal residents, planners, and government officials about the damaging effects of storm surge, a phenomenon where storm activity can temporarily raise sea levels well beyond the normal tide range. In addition, surging waves associated with these storms have force which can cause great damages to property and infrastructure and put the safety of coastal residents at risk. The study of these effects took on renewed urgency as a result of the more than $\$ 50$ billion in damage caused by Hurricane Sandy, much of it attributed to the effects of storm surge (NCDC 2013, Abel et al. 2012). In recent years, researchers also have begun to link elevated storm surges with sea-level rise (SLR) associated with climate change. For example, an assessment of climate-related risks to the Northeast established that storm surge flood heights which have historically been reached with a 1 in 100 year probability could increase in frequency to rates as high as once every four years, simply because SLR will provide a higher "launch point" for all future storm surges (Frumhoff et al. 2007). That report acknowledged that a quantitative assessment of the likely damages from these events was not yet possible, but recent research has made progress in identifying flood heights from the combined effect of storm surge and SLR over broad areas (Bromirski et al. 2012); in linking models of storm activity to storm surge models for selected areas (Lin et al. 2012); and in conceptualizing the long term damages of storm surge (Kirshen et al. 2012). These effects have been assessed in the coastal chapter of the US Global Change Research Program's National Climate Assessment (Melillo et al. 2014), which acknowledges that no national assessment of the joint effect of SLR and storm surge has yet been undertaken.

In this paper, we for the first time extend previous efforts to comprehensively link a tropical cyclone simulation model with a model of storm surge, and assess economic damages, costeffective adaptation options, and the effects of global greenhouse gas (GHG) mitigation policy using the US Environmental Protection Agency's (USEPA's) National Coastal Property Model (NCPM) across the coastline of the contiguous US.

The model is tested using multiple SLR scenarios, including those incorporating estimates of dynamic ice-sheet melting, two GHG mitigation policy scenarios, and multiple general circulation model climate sensitivities. Detailed descriptions of the GHG emissions scenarios, along with projections of global climate change and SLR, are provided in Paltsev et al. (2013). In short, three emission scenarios are used: a reference or 'business as usual' (REF), and two scenarios representing futures with policies that limit global GHG emissions such that radiative forcing levels in 2100 are stabilized at $4.5 \mathrm{~W} / \mathrm{m}^{2}$ (Policy 4.5 ) or $3.7 \mathrm{~W} / \mathrm{m}^{2}$ (Policy 3.7). The scenarios used here reflect results for global SLR through 2100 , but also incorporate adjustments to account for the omitted effect of dynamic ice-sheet melting, a potentially important factor for SLR projections (Meier et al. 2007). Dynamic ice-sheet melting scenarios incorporate estimates from the empirical model of Vermeer and Rahmstorf (2009), and use as inputs the decadal trajectory of global average air temperature results from the IGSM climate model (Paltsev et al. 2013) (see online supplemental material for additional detail on the climate modeling and the SLR results for these scenarios). As expected, the stabilization scenarios yield lower levels of SLR, but it takes several decades for GHG mitigation to affect SLR - for 
example, the REF scenario yields SLR of $142 \mathrm{~cm}$ by 2100 (relative to 1990 levels), while the Policy 3.7 yields SLR of about $94 \mathrm{~cm}$, but these two scenarios yield almost identical SLR by 2045.

\section{Methods and data}

The NCPM comprehensively examines the contiguous US coast at a detailed $150 \mathrm{~m} \times 150 \mathrm{~m}$ grid level; incorporates site-specific elevation, land subsidence, and property value data; estimates cost-effective responses to the threat of inundation; and provides economic impact results for three categories of response: shoreline armoring, beach nourishment, and property abandonment (Neumann et al. 2010a and 2010b) (see online supplemental material for additional methodological details for the NCPM). The model was originally developed to address the threat of SLR, and was modified for this work to incorporate the effects of storm surge on estimates of vulnerability, impact, adaptation response, and economic damages.

\subsection{Incorporating storm surge into the NCPM}

Incorporating storm surge requires modifying the NCPM in three ways: 1) Estimating a cumulative distribution function for location-specific storm surge; 2) Estimating a cumulative distribution function for economic damages; and 3) Adding a new response option (property elevation) that represents a cost-effective alternative in areas subject to episodic flooding but which are not permanently inundated. The first modification relies on the work of Emanuel et al. (2008) for the East and Gulf Coast sites where tropical cyclone activity is the primary threat. Emanuel et al. have developed a method for estimating the generation, track, intensity, and landfall location(s) of simulated tropical cyclone events in climate states represented by large-scale climatology or by global climate models. The wind field output from this simulated storm-generation activity is used as an input in the National Oceanic and Atmospheric Administration's Sea, Lake, and Overland Surge from Hurricanes (SLOSH) model to estimate storm surge depths resulting from these hypothetical storms (Jelesnianski et al., 1992). SLOSH takes into account the storm's pressure, size, forward speed, forecast track, wind speeds, and topographical data. The result is a cumulative density function for storm surge over a centurylong time scale at any given location.

Tropical cyclones only rarely strike the West Coast, but periodic storms do cause coastal flooding. For the West Coast sites, therefore, we relied on an analysis of historic tide gauge water levels following Tebaldi, Strauss, and Zervas (2012). Hourly and monthly data from the gauges are used to elicit historic patterns of extreme high water events. A peak-over-threshold analysis is performed to select extreme high water events using a threshold corresponding to the 99th percentile of each gauge's distribution of observed water levels. The probability of these extreme events is then modeled using a generalized Pareto distribution, the parameters of which can be used to estimate a cumulative density function for storm tide at each gauge. For this analysis, we use SLOSH and the West Coast tide gauge data to model storm surge in the base case (without SLR) over the 21 st century. This storm surge cumulative density function is then modified to reflect the effects of SLR on surge height by simply increasing the surge height by the height of relative SLR at any given point in time.

The second modification to the NCPM follows the approach applied in Kirshen et al. (2012) to estimate a cumulative distribution function for economic damages. First, the storm surge cumulative density function from SLOSH is used to develop an exceedance curve of surge heights. If damages are assigned to each point along the storm surge exceedance curve, 
then it becomes a damage frequency curve. The area under this curve is the annual expected value of storm surge damage. The model calculates damages at eight points along the storm surge exceedance curve (points roughly corresponding to the 2-year, 5-year, 10-year, 20-year, 50-year, 100-year, 250-year, and 500-year surge level) using cell-specific data on elevation, property value, and structure and contents depth-damage functions from the U.S. Army Corps (USACE 2000; USACE 2003). These damage values and their corresponding exceedance probabilities are used to estimate the annual expected value of storm surge damage. The storm surge analysis is run on a decadal basis in the NCPM to keep processing time within reasonable limits; therefore, the annual damage estimate is multiplied by ten to estimate damages over the 10-year time period. This value is then added to damages calculated in previous time periods to estimate cumulative storm surge damage.

The final modification made to the NCPM is the addition of an elevation response option. This response is only allowed as an adaptation to storm surge. We assume a fixed cost to elevate a structure as well as a cost based on amount of fill needed, consistent with the elevation option used in Neumann et al. (2010a).

With these modifications, the NCPM is able to calculate storm surge damage for cells at risk. Storm surge damages are calculated for all cells with an elevation less than the height of the future (21st century) 500-year storm surge. Note that the effect of adaptation means that some cells with elevation below the 500-year storm surge height are actually not at risk from storm surge, precisely because cells seaward of some vulnerable cells may be modeled to implement a protection response (i.e., armor or nourish), providing protection to the landward cells. The model relies on a "contour analysis" to identify cells that are unprotected and at risk. The contour analysis defines contours based on proximity to open water. Cells adjacent to open water are defined as the first contour. For each cell in this contour, the model first determines whether the cell is at risk. Cells that have armored or nourished are considered "not at risk" from a storm event less than the 100-year surge level (cells protect to withstand a 100year surge level). Abandoned and elevated cells remain "at risk" from all storm events. Storm surge damage for at-risk cells includes damages from all storms, while storm surge damage for not-at-risk cells includes only damage from storms that "overtop" the protection, or storms greater than the 100-year surge level.

The model determines an adaptation response for at-risk cells based on the estimated decadal storm surge damage. In each time period, a cell's decadal storm surge damage is compared to its property value to determine its response to the threat of storm surge. If the decadal storm surge damage is greater than total property value (structure and land), the cell will be abandoned. If the decadal storm surge damage is less than property value and also less than protection costs, the cell will temporarily incur storm surge damage. If the decadal storm surge damage is less than property value, but greater than protection cost, the property will be protected. The model contains two protection options for storm surge - elevation and armoring (although beach nourishment can also provide some protection from surge). The model chooses the protection option that costs less overall.

After completing the above process for the first contour, the model moves onto cells within the next contour and repeats the process. Cells adjacent to at risk (i.e., unprotected) cells from the first (or previous) contour are considered at risk. Adjacent cells include those in both the cardinal and intercardinal directions. The contour analysis continues until all cells have been analyzed.

\subsection{National extrapolation}

We ran the NCPM to determine the cost of adaptation to and damage from storm surge for 17 multi-county study areas on the East coast (Barnstable, MA; New York, NY; Ocean County, 
NJ; Virginia Beach, VA; Wilmington, NC; Charleston, SC; Jacksonville, FL; and Miami, FL) Gulf coast (Tampa, FL; Pensacola, FL; Mobile, AL; New Orleans, LA; and Galveston, TX), and West coast (Southern California; Northern California; Oregon State; and Washington State). The results of this analysis were extrapolated to the remaining un-modeled coastal counties to calculate a national estimate of tropical cyclone-related costs.

The goal of the extrapolation was to assign to the unmodeled counties a ratio of SLR and storm surge costs to SLR-only costs, using the results from modeled counties. Note that a comprehensive estimate of the SLR-only costs result from running the model without storm surge effects, using the older version of the NCPM described in Neumann et al. (2010a, b), so the ratio could be used to estimate total SLR and storm surge costs in unmodeled counties. We first attempted to estimate a model for the ratio, using county attributes such as location, area, property value at risk, population, and shoreline length. The resulting model, however, did not have sufficient explanatory power $\left(\mathrm{R}^{2}\right.$ of 0.29 and statistically insignificant coefficients).

As a next best alternative, we chose to use a discrete approach of assigning ratios of SLR and storm surge costs to SLR only costs from the modeled counties to the unmodeled counties. The discrete approach relied on a two-step process to "twin" modeled with unmodeled counties. First, we limited the matching process to modeled counties within the same coastal region (East, Gulf, or West Coast) and sought the closest multi-county study area-note that this criteria eliminated assigning Gulf Coast areas to East Coast counties, which may have been an issue in some Florida counties, an outcome we sought to avoid because of the fundamentally different nature of storm surge risk on these two coasts. Second, we assigned the unmodeled counties to a modeled county within the closed "same coast" study area based on the closest match for property value at risk. To illustrate the approach, consider Baltimore County in Maryland. This county is first assigned to the multi-county Ocean County, NJ study area based on proximity, and then assigned to Ocean County itself based "closest match" to the value per acre of the property at risk within the county (approximately $\$ 330$ million in Baltimore County and $\$ 290$ million in Ocean County).

The ratio of SLR and storm surge costs to SLR only costs, calculated under the REF $3.0^{\circ} \mathrm{C}$ scenario for the assigned modeled county, is then applied to the SLR only results to calculate SLR and storm surge costs for the unmodeled county. The national estimate of tropical cyclone-related costs under the various SLR scenarios is calculated as the sum of storm surge and SLR costs for the counties modeled directly in the NCPM, and storm surge and SLR costs for the counties calculated using the extrapolation process described above.

\section{Results}

Results of our analysis of adaptation to SLR across the seven analyzed scenarios, incorporating dynamic ice sheet melting, are presented in Fig. 1. Total undiscounted costs of adaptation to SLR (excluding storm surge) through 2100 range from $\$ 470$ billion to $\$ 610$ billion under the REF scenarios, depending upon the climate sensitivity value applied, and $\$ 400$ billion to $\$ 510$ billion under the GHG mitigation policy scenarios. Therefore, the benefits of the mitigation scenarios range from $\$ 65$ billion to $\$ 98$ billion. ${ }^{1}$ The largest share of the costs associated with adaptation to SLR are associated with shoreline armoring, followed by nourishment, and the value of abandoned property.

\footnotetext{
${ }^{1}$ Discounted at $3 \%$ (2005\$ with a 2015 base year), these estimates range from $\$ 200$ billion to $\$ 230$ billion for the REF scenarios and $\$ 190$ billion to $\$ 220$ billion for the policy scenarios, thereby yielding mitigation benefits ranging from $\$ 9.4$ billion to $\$ 14$ billion (see Online Resource 1 for additional detail on discounted results).
} 


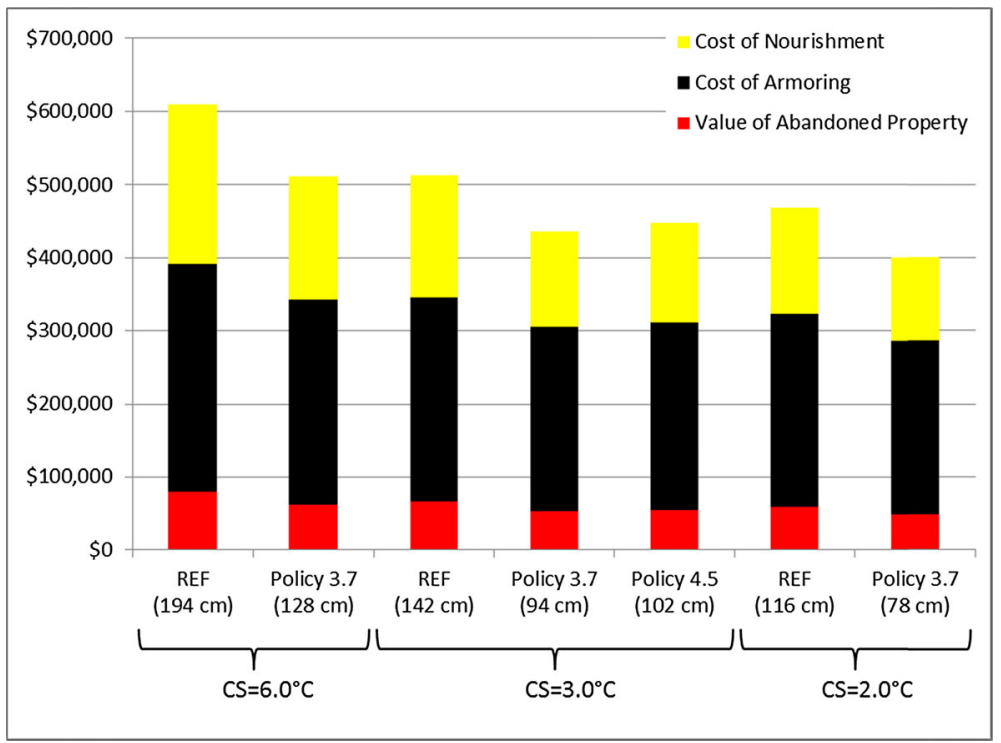

Fig. 1 Cumulative total costs of adaptation in the contiguous US by 2100 for sea-level rise with dynamic ice sheet melting, undiscounted (\$ million). CS is climate sensitivity of the underlying general climate model

As described above, we ran the NCPM to determine the cost of adaptation to and damage from storm surge for 17 multi-county study areas on the East, Gulf, and West Coasts. Figure 2 provides the results of this analysis by scenario across the 17 modeled storm surge sites. This figure shows that in the modeled storm surge sites only, the costs associated with storm surge through 2100 range from $\$ 540$ billion to $\$ 610$ billion under the REF scenarios, depending

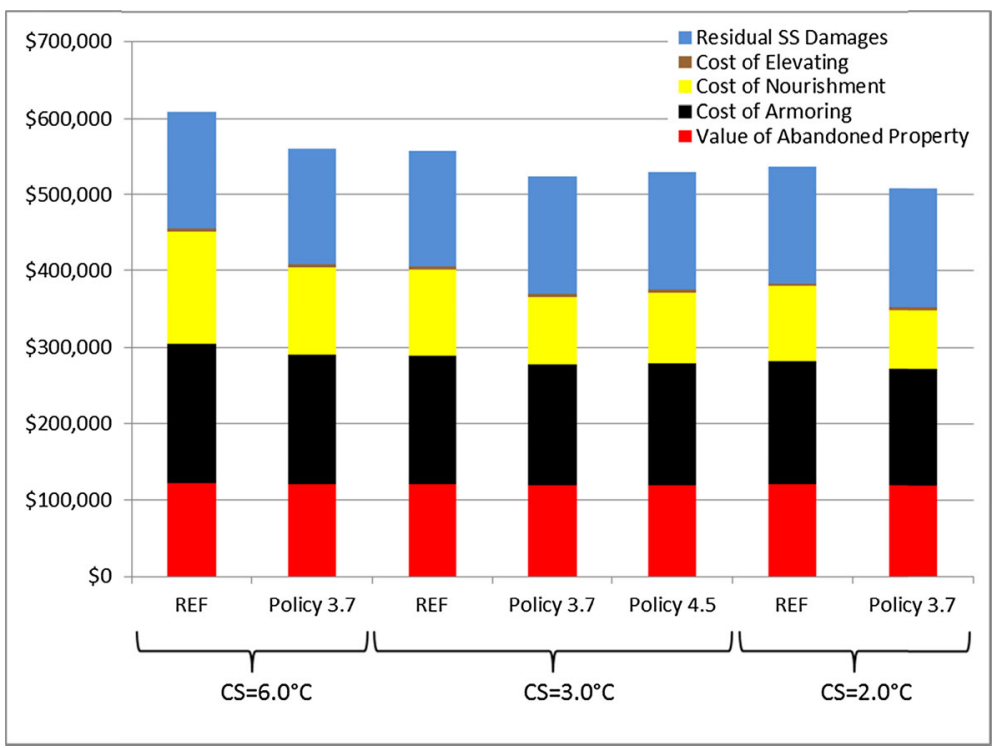

Fig. 2 Cumulative total costs of adaptation by 2100 for sea-level rise with dynamic ice sheet melting and storm surge for the 17 modeled sites only, undiscounted (\$ million) 
upon the climate sensitivity value applied, and $\$ 510$ billion to $\$ 560$ billion under the policy scenarios. Benefits of the GHG mitigation policy scenarios range from \$28 billion to $\$ 49$ billion. The largest share of the costs associated with adaptation to SLR and storm surge are associated with shoreline armoring, followed by nourishment, the value of abandoned property, and finally elevating. In addition, a large portion of the costs are associated with residual storm surge damages which occur during storms with surge greater than the height of protection (the NCPM assumes that armoring, nourishment, and elevation is done to protect sufficiently from a 100-year storm) and when the cost-efficient adaptation option is to do nothing and accrue damages.

Figure 3 provides a site-specific comparison of the SLR only to the SLR and storm surge results under the REF $3.0^{\circ} \mathrm{C}$ scenario with dynamic ice sheet melting. Figure 3 also depicts the storm surge study areas upon which the national extrapolation was based. Total costs of adaptation to SLR through 2100 range from $\$ 1.3$ billion in Washington State to \$51 billion in Miami, increasing to $\$ 1.6$ billion in Washington State to $\$ 130$ billion in Miami when also considering adaptation to storm surge. In the 17 study areas analyzed, the change in the total cost of adaptation when also considering storm surge, compared to SLR only, ranged from zero percent in Oregon State to an increase of $420 \%$ in Tampa.

The results of the national extrapolation are provided in Fig. 4 for each of the seven scenarios analyzed. Total undiscounted costs of adaptation to SLR and storm surge through 2100 range from $\$ 930$ billion to $\$ 1.1$ trillion under the REF scenarios, depending upon the climate sensitivity value applied, and $\$ 840$ billion to $\$ 980$ billion under the different policy scenario/climate sensitivity combinations. This represents an increase of 84 to $110 \%$ over the

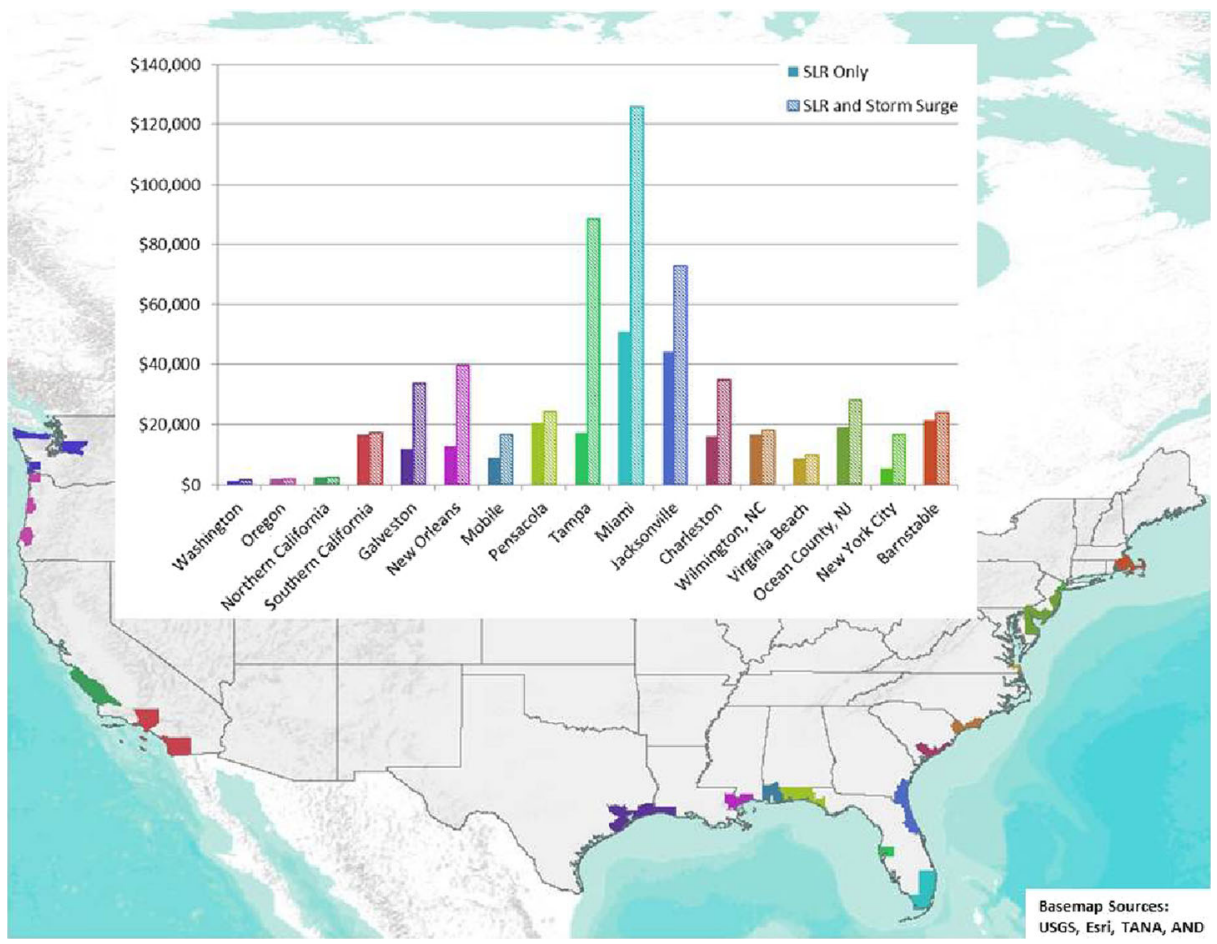

Fig. 3 Total costs of adaptation by 2100 under reference $3^{\circ}$ scenario with dynamic ice sheet melting, undiscounted (\$ million) 


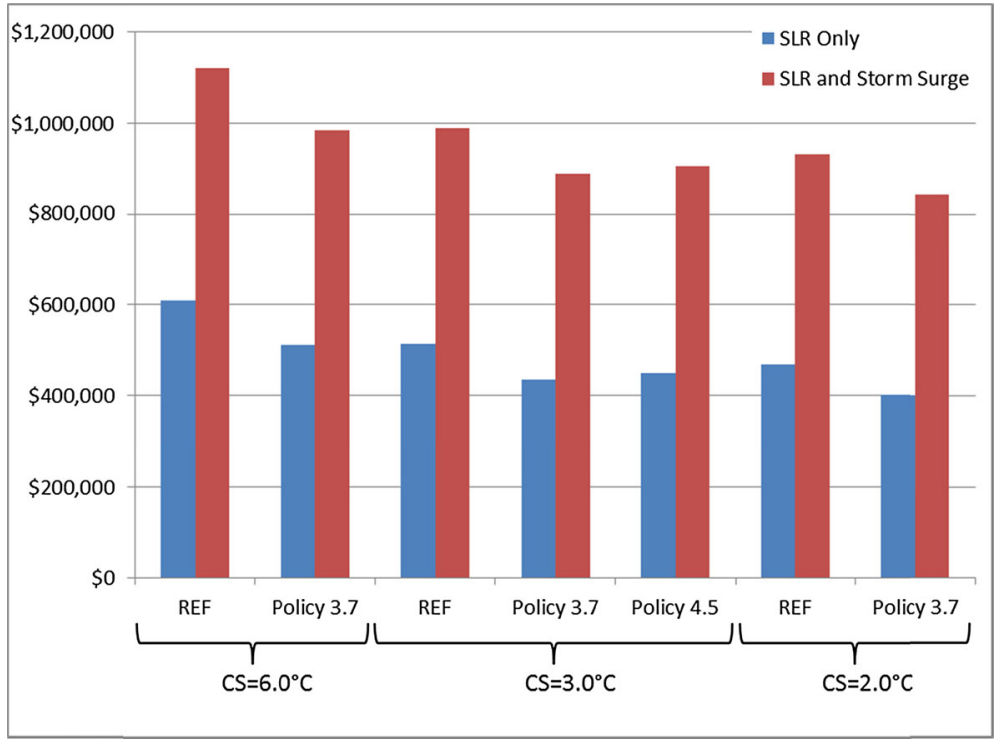

Fig. 4 Comparison of cumulative total costs of adaptation by 2100 in the contiguous US for sea-level rise with dynamic ice sheet melting with and without storm surge, undiscounted (\$ million)

costs of adaptation to SLR only. Benefits of the GHG mitigation policy scenarios range from $\$ 84$ billion to $\$ 140$ billion when considering costs associated with adaptation to both SLR and storm surge. ${ }^{2}$ Figure 5 depicts the cumulative benefits of GHG mitigation over time under the three degree climate sensitivity alternative. This figure shows that benefits do not begin to substantially accrue until mid-century. Beginning around 2050, benefits accrue rapidly and at a more substantial pace when also considering impacts associated with storm surge.

\section{Discussion and conclusions}

The results presented in this paper indicate the importance of considering the combined effect of SLR and storm surge when analyzing the risk of climate change to coastal property. Incorporating episodic storm surge increases the undiscounted national scale costs associated with adaptation by approximately a factor of two, compared to an SLR only estimate. Further, GHG mitigation results in cumulative undiscounted avoided costs of up to $\$ 98$ billion through 2100 when considering SLR alone and up to $\$ 140$ billion when considering the joint effect of SLR and storm surge. Because GHG mitigation has a delayed effect on SLR, the majority of the benefits associated with mitigation are not realized until mid-century. Benefits increase rapidly beginning around 2050. In addition, it is interesting to note the relative insensitivity of results for SLR and storm surge impacts in Figs. 1 and 2 to alternative climate sensitivities. While differences between scenarios are large in absolute terms, suggesting substantial benefits of mitigation scenarios, the results are consistent with the understanding that SLR is

\footnotetext{
${ }^{2}$ Discounted at $3 \%$ (2005\$ with a 2015 base year), these estimates range from $\$ 680$ billion to $\$ 730$ billion for the REF scenarios and $\$ 660$ billion to $\$ 700$ billion for the policy scenarios, thereby yielding mitigation benefits ranging from $\$ 18$ billion to $\$ 29$ billion (see online supplemental material for additional detail on discounted results).
} 


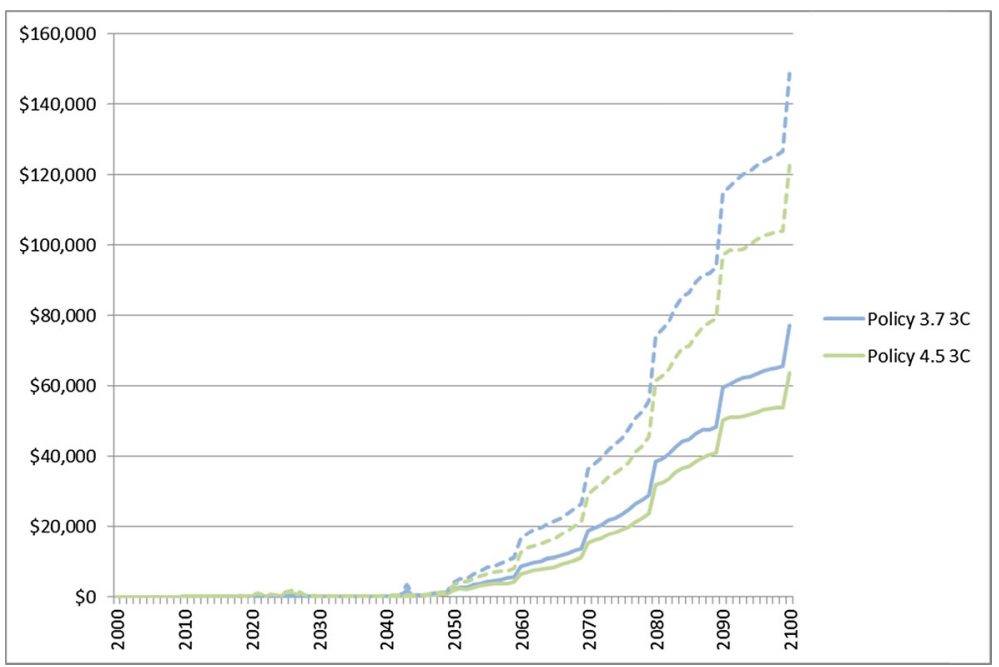

Fig. 5 Cumulative benefits in the contiguous US for sea-level rise with dynamic ice sheet melting with (dashed line) and without (solid line) storm surge, undiscounted (\$ millions)

difficult to mitigate, that mitigation action does have an impact until after 2050, and that a substantial portion of the SLR projected for 2100 is already committed to as a result of heat energy historically accumulated in oceans.

While mitigation does have a substantial effect on reducing future damages of climate change on coastal property, adaptation plays a crucial role in responding to the threat. In particular, due to the high value of coastal property, driven by the high amenity value of coastal property, the optimal adaptation response more often involves protection rather than abandonment of property. When considering SLR only, costs associated with armoring and beach nourishment represent approximately 59 and $29 \%$ of the total costs associated with adaptation, respectively. Abandonment of property makes up the remaining $12 \%$ of these costs. When also considering storm surge in the 17 modeled sites, costs associated with armoring, nourishment, and elevation represent a smaller share of the costs associated with adaptation, between 66 and $74 \%$. Abandonment becomes an optimal adaptation option in more cases due to the significant damages caused by storm surge. This is illustrated in Fig. 6 for the Tampa study site - the left panels illustrate the cost-effective adaptation response to SLR risks, with red areas indicating abandonment, black areas lines of armoring defense, yellow areas beach nourishment, and brown areas structure elevation. The incremental effect of dynamic ice sheet melting is shown in the bottom panels. A significant difference in abandoned area is evident when comparing the left and right panels. In particular, the red areas in the low elevation east bay show great sensitivity to storm surge. A similar map for New York City would show less abandonment and more protection and elevation in response to risks of episodic flooding, owing to higher property values in New York City's vulnerable areas.

It is also important to note that there are significant residual impacts due to storm surge after adaptation measures are in place. These damages make up between 25 and $31 \%$ of the total costs associated with SLR and storm surge in the modeled sites. The residual impacts include two components. The first component arises from areas where episodic flooding occurs, but where the extent and damage from flooding are not so great as to trigger an abandonment response. The second component arises in areas where protection is warranted, but there is 


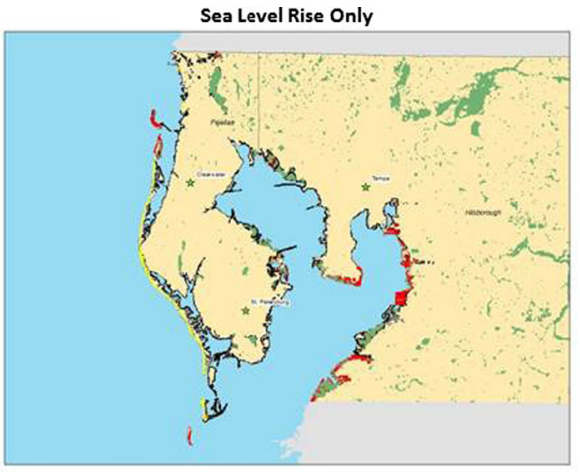

Sea Level Rise with Dynamic Ice Sheet Melting

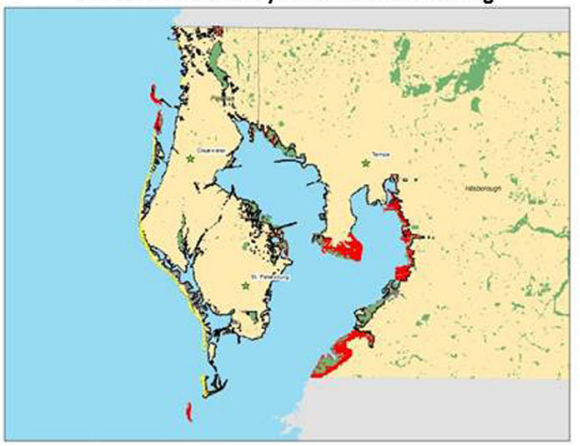

Wetlands

Abandon
Sea Level Rise with Storm Surge

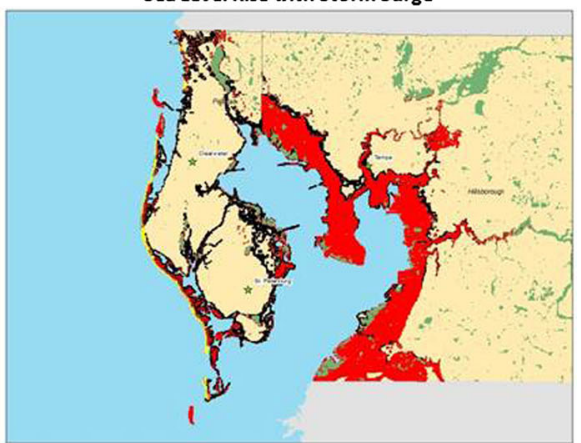

Sea Level Rise and Storm Surge with Dynamic lce Sheet Melting

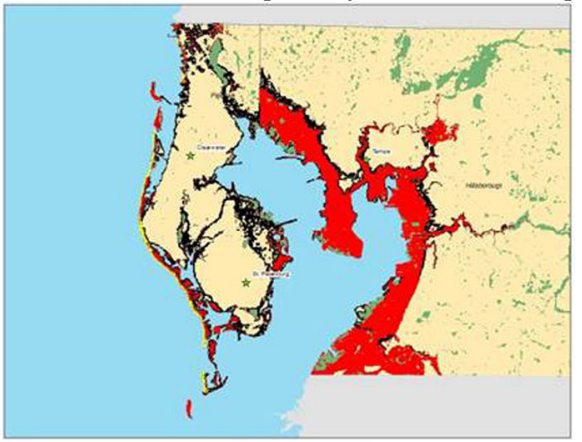

Elevate

Armor

Nourish

Fig. 6 Effect of incorporating storm surge in economic impact estimates for Tampa, Florida

infrequent overtopping of the protection for rare but severe storms. The first component accounts for the largest portion of residual impacts, on an expected value basis, but the second component, associated with severe storms, may underestimate effects because of our current inability to estimate indirect effects such as loss of critical infrastructure, business interruption, and debris removal costs that may be a much larger component of damages than the direct structure damage in these more severe storms.

The effect of storm surge varies dramatically by location. As expected, costs associated with storm surge vary geographically due to topography, value of coastal property, and the nature of storms. In some areas, responding to the gradual effects of SLR provides nearly sufficient protection from storm surge as well. But in many other areas, storm surge is significant amplifying factor. Low lying areas with significant coastal development that have greater storm activity have the greatest costs associated with storm surge. Under the REF scenario with $3{ }^{\circ} \mathrm{C}$ climate sensitivity, the four sites with the greatest increase in costs when also considering storm surge are Tampa (420\% increase), New York City (220\% increase), New Orleans (210\% increase), and Galveston (190\% increase). In recent years major storms have hit the New York, New Orleans, and Galveston areas showing firsthand how susceptible these areas are to storm surge.

The approach presented in this paper does have some limitations. For example, specific to this addition of damage from storms, we are currently unable to capture damages from wind or rain associated with coastal storms. The spatial extent as well as the magnitude of the damages are likely to increase when also considering the effect of wind and rain (see Mendelsohn et al. 2012 for more 
details on the potential for wind damage from tropical cyclones). In addition, our approach is designed to analyze impacts to coastal property, but does not explicitly account for impacts to infrastructure and ecosystem services. For infrastructure, a reasonable case can be made that most if not all services from public infrastructure are capitalized in private property values, but the mechanism by which those services erode with SLR and storm surge, and in turn affect property values, is incompletely understood at the national scale our model is deployed. Ecosystem services are even more complex in the manner in which they contribute to local property values, and have the added dimension of providing external benefits beyond local property values (e.g., healthy coastal wetlands contribute to fisheries productivity, in ways that are not likely reflected in coastal property values). Some of these effects will be non-linear-for example, if SLR and storm surge damage a critical road link from coastal areas to population centers, a non-marginal effect could result; for these types of effects, new techniques may be needed, or consideration of larger protection projects (such as the massive storm surge barriers suggested for New York and Boston in the recent past - while these are not currently considered by the model, they have been assessed on a projectspecific basis). Effects on beach width might also be considered, for the effect on recreational values. Future research can contribute to overcoming these limitations, and should focus on the property value dynamics by which damages to infrastructure and ecosystems can contribute to our damage estimates, either through separable modules or through effects on property values (and hence, damages) through time.

The model also does not include post-disaster damages such as those from power outages and lost productivity (Abel et al. 2012). We recognize that the effect of a major storm on the economy of a region may be felt long after the actual storm. In addition, for the East and Gulf coasts, our analysis focuses on storms of tropical origin. Extra-tropical storms also cause significant damage but are not addressed here (see Narita et al. 2010 for more information).

Three key directions emerge for further research. First, while the sea-level rise impacts and adaptation literature has firmly established that adaptation such as that modeled here is a very costeffective response to coastal inundation and flood risks, recent storm events have shown that in many cases cost-effective adaptation measures have yet to be adopted. This suggests that further attention should be paid to establishing the level of economic assets that are vulnerable to the coastal SLR and storm surge risks modeled here, absent adaptation, and evaluating how incremental "tiers" of adaptation action can serve to mitigate those risks, with costs and benefits tracked along the way. Further, while our model focuses on an economic balancing of the costs and benefits of adaptation, other paradigms could be considered and might either better explain past adaptive behavior, or provide useful insights for encouraging cost-effective adaptation. In prior iterations of the model (Neumann et al. 2010a), we explored other criteria for adaptation decisionmaking, including explicit protection of ecologically sensitive areas, but the next frontier also needs to consider processes of learning and, likely, more explicit roles for disentangling public and private incentives for efficient adaptation (including who pays for adaptation).

Second, for computational reasons we focus our national estimates on the application of the SLOSH storm surge model — but in many locations a more detailed hydrodynamic model (e.g., ADCIRC) that includes all key physical processes (e.g., wind, waves, freshwater discharge) is needed to better characterize surge risks. Further site-specific comparisons are needed along the lines of Lin et al. (2012) that include evaluation of the impact on economic assessments such as ours when using these more refined storm surge tools. In addition, in areas identified at high risk from storm surge likely justify a modest analytic investment in ADCIRC modeling, in part to provide better assurance that planned adaptations to storm surge can be both effective and cost-effective, before the much larger infrastructure investments are made. Third, recent research suggests that SLR is likely to manifest with regional "hotspots" of unusually high SLR. One of these hotspots is the US North Atlantic coast, an area with substantial economic 
value near the coast (Sallenger et al. 2012). Future analyses should take into account these emerging findings and test the sensitivity of impact and adaptation cost results to higher levels of SLR that reflect the non-uniform influence of currents and other local factors.

Acknowledgments The authors wish to acknowledge the financial support of the USEPA's Climate Change Division (Contracts EP-D-09-054 and EP-BPA-12-H-0024). The views expressed in this document do not necessarily represent those of the USEPA. In addition, we are grateful to Benjamin Strauss of Climate Central for providing historic storm data for selected West Coast sites.

Open Access This article is distributed under the terms of the Creative Commons Attribution License which permits any use, distribution, and reproduction in any medium, provided the original author(s) and the source are credited.

\section{References}

Abel, J R, Bram J, Deitz R, Orr J. (2012) What are the costs of Superstorm Sandy? Federal Reserve Bank of New York. Available online at http://libertystreeteconomics.newyorkfed.org/2012/12/what-are-the-costs-ofsuperstorm-sandy.html

Bromirski PD, Cayan DR, Graham N, Flick RE, Tyree M (Scripps Institution of Oceanography) (2012) Coastal Flooding Potential Projections: 2000-2100. California Energy Commission, CEC500-2012-XXX

Emanuel K, Sundararajan R, Williams J (2008) Hurricanes and global warming: results from downscaling IPCC AR4 Simulations. Bull Am Meteorol Soc 89:347-367

Frumhoff PC, McCarthy JJ, Melillo JM, Moser SC, Wuebbles DJ (2007) Confronting climate change in the U.S. Northeast: science, impacts, and solutions. Synthesis Report of the Northeast Climate Impacts Assessment (NECIA). Cambridge, MA: Union of Concerned Scientists (UCS)

Jelesnianski, CP, Chen J, Shaffer WA (1992) SLOSH: Sea, lake, and overland surges from hurricanes. NOAA Technical Report NWS 48, National Oceanic and Atmospheric Administration, U. S. Department of Commerce, Washington, DC

Kirshen P, Merrill S, Slovinsky P, Richardson N (2012) Simplified method for scenario-based risk assessment adaptation planning in the Coastal Zone. Clim Chang 113:3-4. doi:10.1007/s10584011-0379-z

Lin N, Emanuel K, Oppenheimer M, Vanmarcke E (2012) Physically based assessment of hurricane surge threat under climate change. Nat Clim Chang 2:462-467. doi:10.1038/nclimate1389

Meier MF, Dyurgerov MB, Rick UK, O'Neel S, Pfeffer WT, Anderson RS, Anderson SP, Glazovsky AF (2007) Glaciers dominate Eustatic sea-level rise in the 21st Century. Science 317:1064-1067

Melillo JM, Richmond TC, Yohe GW (eds) (2014) Climate Change Impacts in the United States: The Third National Climate Assessment. US Global Change Research Program. doi:10.7930/J0Z31WJ2

Mendelsohn R, Emanuel K, Chonabayashi S, Bakkensen L (2012) The impact of climate change on global tropical cyclone damage. Nat Clim Chang 2:205-209. doi:10.1038/nclimate1357

Narita D, Tol R, Anthoff D (2010) Economic costs of extratropical storms under climate change: An application of FUND. J Environ Plan Manag 53(3):371-384

NCDC (National Climatic Data Center) (2013) Billion-Dollar U.S. Weather/Climate Disasters 19802013. National Climatic Data Center, Asheville, NC. Downloaded from http://www.ncdc.noaa.gov/ billions/

Neumann JE, Hudgens DE, Herter J, Martinich J (2010a) Assessing sea-level rise impacts: a GIS-based framework and application to coastal New Jersey. Coast Manag 38(4):433-455

Neumann JE, Hudgens DE, Herter J, Martinich J (2010b) The Economics of Adaptation along Developed Coastlines. Wiley Interdiscip Rev Clim Chang 2(1):89-98

Paltsev S, Monier E, Scott J, Sokolov A, Reilly J, Gao X, Schlosser A (2013) Integrated economic and climate projections for impact assessment. Clim Change. doi:10.1007/s10584-013-0892-3

Sallenger AH, Doran KS, Howd PA (2012) Hotspot of accelerated sea-level rise on the Atlantic coast of North America. Nat Clim Chang 2:884-888 
Tebaldi C, Strauss B, Zervas C (2012) Modeling sea-level rise impacts on storm surges along US coasts Environ. Res Lett 7:014032

USACE (2000) Economic Guidance Memorandum (EGM) 01-03, Generic Depth-Damage Relationships

USACE (2003) Economic Guidance Memorandum (EGM) 04-01, Generic Depth-Damage Relationships for Residential Structures with Basements. 10 October 2003

Vermeer M, Rahmstorf S (2009) Global sea level linked to global temperature. Proc Natl Acad Sci 106(51): $21527-21532$ 